\title{
Ruminal pH and temperature, papilla characteristics, and animal performance of fattening calves fed concentrate or maize silage-based diets
}

\author{
Raúl Bodas $^{1 *}$, Raquel Posado ${ }^{1}$, Daniel José Bartolomé1, María José Tabernero de Paz ${ }^{1}$, \\ Pedro Herráiz ${ }^{2}$, Eduardo Rebollo² Luis Jesús Gómez $^{3}$, and Juan José García ${ }^{1}$
}

Feeding systems can play an important role, not only in beef farm profitability but also in animal health and performance. Fourteen Avileña-Negra Ibérica bulls, with an initial weight of $270 \mathrm{~kg}$ (SE $22.6 \mathrm{~kg}$ ) and aged $223 \mathrm{~d}$ (SE 16.2) were used to study the effect of two feeding systems on ruminal $\mathrm{pH}$ and temperature and animal performance when calves were kept in loose housing conditions. Feeding systems were barley (Hordeum vulgare L.) grain-based concentrate plus barley straw (CONC) and maize (Zea mays L.) silage-based total mixed ration (TMR). Internal wireless boluses were used to collect $\mathrm{pH}$ and temperature values every $10 \mathrm{~min}$ throughout the measurement period $(15 \mathrm{~d})$. Diet did not modify $(\mathrm{P}>$ 0.10) average daily gain, carcass weight, dressing percentage, ruminal mucosa color, or papilla counts. Papilla width and papilla width/lamina propria thickness were significantly lower $(\mathrm{P}<0.05)$ in TMR than in CONC animals. Time spent below ruminal $\mathrm{pH}$ thresholds of 7.0, 6.6, 6.2, and 5.8 and the corresponding areas under the curve were higher $(\mathrm{P}$ $<0.05$ ) for animals fed under the TMR system. No significant changes were observed between experimental treatments in parameters related to ruminal temperature or estimated number of times that the animals were drinking during the day $(\mathrm{P}>0.10)$. Although animal performance is not affected, feeding fattening calves on a concentrate plus barley straw diet can result in better rumen conditions than using maize silage-based TMR.

Key words: Acidosis, feeding system, monitoring, rumen, total mixed ration.

\section{INTRODUCTION}

Fattening cattle are fed under different feeding systems depending on farm facilities, consumer preferences, and economic circumstances. While some of these systems are mainly based on pasture and silage, others are based on the supply of concentrate feed and forage, both ad libitum. Some farmers consider the possibility of increasing productivity by increasing the amount of concentrate offered in the last months of the fattening period (Cooke et al., 2004; O'Kiely, 2011). On the other hand, given the sudden and constant rise in the prices of ingredients for concentrates, farmers are more interested in reducing the use of concentrates and turning to foragebased diets (Casasús et al., 2012).

The effects of these types of diets (forage- and concentrate-based) on animal performance and carcass

${ }^{1}$ Instituto Tecnológico Agrario, Subdirección de Investigación y Tecnología, Finca Zamadueñas, Ctra. Burgos, km 119, 47071 Valladolid, España. "Corresponding author (bodrodra@itacyl.es).

${ }^{2}$ Asociación Española de Criadores de Ganado Vacuno Selecto de Raza Avileña-Negra Ibérica, Padre Tenaguillo, 8, 05004 Ávila, España.

${ }^{3}$ Universidad de Extremadura, Facultad de Veterinaria, Avda. de la Universidad s/n 10003 Cáceres, España.

Received: 19 December 2013.

Accepted: 16 June 2014.

doi:10.4067/S0718-58392014000300005 and meat characteristics have been extensively studied. Concentrate-based rations allow faster, more controlled, and predictable growth rates than forage-based diets (Cooke et al., 2004; Walsh et al., 2008; O'Kiely, 2011). Animals can achieve similar growth rates when they are fed forage-based diets, but these are associated with higher feed intake and worse feed to gain ratios, while still being economically competitive (Casasús et al., 2012).

Feeding management can affect not only animal performance but also animal welfare. Using concentratebased rations has been criticized for its consequences on ruminal $\mathrm{pH}$ and the development of subacute ruminal acidosis processes (González et al., 2012). Using concentrates and decreasing ruminal $\mathrm{pH}$ values are two closely interrelated factors and there is no clear discrimination between the two (Calsamiglia et al., 2012). It is necessary to focus not only on $\mathrm{pH}$ control, but also on how this is affected by the type of feed consumed by animals and the way this feed is supplied and consumed.

The development of subacute acidosis cannot be associated to early clinical symptoms (Nagaraja and Titgemeyer, 2007; Wahrmund et al., 2012). While early detection methods were based on using a wired $\mathrm{pH}$ probe placed in the rumen through a ruminal cannula, the more advanced methods are based on wireless $\mathrm{pH}$ probes, which end up in the reticulo-rumen for the duration of the animal's life. They allow accurate $\mathrm{pH}$ and temperature 
readings in real time. These probes are used in dairy cattle herds to provide early detection of management practices that increase the risk of sub-clinical acidosis, thus helping to prevent its negative consequences.

The aim of this research was to study the effect of two feeding management systems (concentrate feed plus barley straw in separate feeding troughs vs. maize silage-based total mixed ration -TMR) on ruminal $\mathrm{pH}$ and temperature dynamics, papilla characteristics, and animal performance of Avileña-Negra Ibérica calves kept in loose housing conditions.

\section{MATERIALS AND METHODS}

\section{Animals and diets}

Fourteen Avileña-Negra Ibérica bulls with an initial body weight of $270 \mathrm{~kg}$ (SE $22.6 \mathrm{~kg}$ ) and aged $223 \mathrm{~d}$ (SE 16.2) were included in the study. Seven animals received barley (Hordeum vulgare L.) grain-based concentrate feed from a hopper feeder (space allowance $15 \mathrm{~cm}$ per head) plus barley straw in long form (unchopped) (CONC group), whereas the other seven received a maize (Zea mays L.) silagebased total mixed ration (TMR) in a bunk feeder (space allowance $45 \mathrm{~cm}$ per head) (TMR group). Ingredients and chemical composition of diets are shown in Table 1 .

Animals were housed in groups under the cover of feedlot facilities in Riocabado (4049'48' N 448' $11^{\circ}$ " W, $906 \mathrm{~m}$ a.s.l., Ávila, Spain). The CONC treatment received $2 \mathrm{~kg}$ barley straw (as-fed basis in a bunk feeder) per animal and per day plus ad libitum fresh concentrate available from a hopper feeder, while TMR was delivered to the bunk feeder for the TMR group once a day (at 10:00 h) after cleaning feed refusal from the previous day (approximately 10\%). Clean fresh water was always available for both groups.

Table 1. Ingredients and chemical composition of two diets offered to loose-housed fattening calves.

\begin{tabular}{lrr}
\hline & $\mathrm{CONC}^{1}$ & $\mathrm{TMR}$ \\
\hline Ingredients (as-fed basis), $\mathrm{g} \mathrm{kg}^{-1}$ & & 740 \\
Maize silage & 335 & 11 \\
Barley grain & 300 & 132 \\
Maize grain & 150 & 49 \\
Dried maize distillers grains & 20 & 50 \\
Soybean meal 44\% crude protein & 10 & 9 \\
By-pass fat & 20 & - \\
Palm oil & 20 & - \\
Sugar beet pulp & 20 & - \\
Palm kernel expeller & 52 & - \\
Rapeseed expeller & 53 & - \\
Wheat middlings & 20 & 9 \\
Vitamin mineral premix & & \\
Chemical composition (DM basis), $\mathrm{g} \mathrm{kg}^{-1}$ & 890 & 473 \\
Dry matter (as-fed basis) & 152 & 139 \\
Crude protein & 201 & 280 \\
Neutral detergent fiber & 60 & 58 \\
Ash & 1438 & 1308 \\
Net energy for fattening, kcal kg-1 ${ }^{-1}$ & \\
\hline
\end{tabular}

${ }^{1}$ CONC animals also received $2 \mathrm{~kg}$ barley straw (92 g moisture, $32 \mathrm{~g}$ crude protein, $928 \mathrm{~g}$ neutral detergent fiber, $559 \mathrm{~g}$ acid detergent fiber, $1.7 \mathrm{~g}$ ether extract, $51 \mathrm{~g}$ ash, and $352 \mathrm{kcal}$ net energy per $\mathrm{kg} \mathrm{DM}$ ) per animal per day.

TMR: total mixed ration.
Animal handling and management was conducted according to Directive 2010/63/EU (Official Journal of the European Union, 2010) for the protection of animals used for scientific purposes.

\section{Ruminal pH and temperature monitoring}

When the animals had been fed the same diet for approximately $3 \mathrm{mo}$, internal wireless smaXtec $\AA$ boluses (smaXtec animal care sales GMBH, Graz, Austria) were used to collect ruminal $\mathrm{pH}$ and temperature data every $10 \mathrm{~min}$. Each bolus ended up in the reticulum (where it remained until the animal was slaughtered) after being calibrated ( $\mathrm{pH} 4$ and 7) and introduced with an oral balling gun following manufacturer instructions. Data were recorded for a period of $15 \mathrm{~d}$.

\section{Animal performance and rumen wall characteristics}

Animals were slaughtered when they reached the body weight at which they are usually sent to abattoir on this commercial farm (between 525 and $550 \mathrm{~kg}$, in this case, $535 \mathrm{~kg}$, SE $8.8 \mathrm{~kg}$ ). The following animal performance data were recorded: weight and age at slaughter, duration of fattening period, total weight gain (animals were weighed once a month), and average daily gain (ADG) during the fattening period, carcass weight, and dressing percentage (carcass weight/weight at slaughter).

Once the animal was eviscerated, the rumen was opened and washed, the color of the mucosa was always visually evaluated (1, clear; 2 , dark) by the same person, and the bolus was recovered. Samples from the dorsal sac of the rumen were taken $(5 \times 5 \mathrm{~cm})$ for histological examination. Samples were fixed by immersion in buffered formaldehyde (4\%) for at least $24 \mathrm{~h}$. After fixation, digital photographs were taken to evaluate mucosal epithelium color (red, blue, and green indices and gray scale) as an indicator of the degree of keratinization (Benavides et al., 2013) with ImageJ 1.43 software (ImageJ, National Institute of Mental Health, Bethesda, Maryland, USA) to process the pictures.

Subsequently, samples were included in cassettes and dehydrated by alcohol ascending scales and then embedded in paraffin (Automatic Tissue Processor TP1020, Leica Microsystems, Nussloch, Germany). Sections, $5 \mu \mathrm{m}$ thick (microtome RM2255, Leica), were stained with hematoxylin-eosin and Masson trichrome. Photomicrographs were taken (Advanced Research Microscope Eclipse 80i, shooting program ACT-1, Nikon Instruments, Tokyo, Japan) of each sample stained with hematoxylin-eosin at $40 \mathrm{X}$ to assess papilla width (total papilla width, AT) and at $200 \mathrm{X}$ to measure lamina propria thickness (ALP).

\section{Analytical procedures}

Procedures described by AOAC (2003) were used to determine DM (AOAC official method 934.01), ash (AOAC official method 942.05), and Kjeldahl $\mathrm{N}$ 
(AOAC official method 976.06). Neutral detergent fiber (expressed as including residual ash) was determined by the Van Soest et al. (1991) method by adding sodium sulfite to the solution.

\section{Statistical analysis}

Animal performance data were subjected to one-way ANOVA with the diet as the only source of variation.

Ruminal $\mathrm{pH}$ and temperature data first were averaged for each day: maximum, minimum, and mean, area under the curve, and time spent below $\mathrm{pH}$ threshold of 7.0, 6.6, $6.2,5.8$, and 5.4. The area under the curve was calculated by multiplying the absolute value of the deviation in $\mathrm{pH}$ by the time $(\mathrm{min}) \mathrm{pH}$ is below the threshold, which is expressed as $\mathrm{pH}$ units per min. The average $\mathrm{pH}$ value for each hour of each day was also calculated for each animal.

Temperature data were summarized as maximum, minimum, mean, and time above 39.0, 39.2,39.4, and 39.6 ${ }^{\circ} \mathrm{C}$. The area under the curve was calculated as indicated for $\mathrm{pH}$. Temperature data for the water intake times of each animal were identified: Temperature shows a sharp decrease followed by a slow increase to approximately pre-water intake temperature (Dye and Richards, 2008). The start of a drinking event was identified when ruminal temperature decreased more than $0.28{ }^{\circ} \mathrm{C}$ from the previous measurement. The end of a drinking event was considered when the temperature was above $38.4{ }^{\circ} \mathrm{C}$ or when it stopped increasing in a period of $10 \mathrm{~min}$.

The $\mathrm{pH}$ and temperature data were subjected to analysis of repeated measures; the covariance structure (first-order autoregressive) was selected by considering the Schwarz Bayesian and Akaike criteria. Diet was considered as a fixed effect, day as a repeated measure, and the animal in the treatment as the subject. A correlation matrix between performance and $\mathrm{pH}$ and temperature data was built. All the analyses were performed with SPSS 16.0 for Windows (IBM Corp., New York, USA).

\section{RESULTS}

Animal performance traits are presented in Table 2. Diet did not modify $(\mathrm{P}>0.10)$ average daily gain, carcass weight, or dressing percentage.

Table 3 shows values of ruminal mucosa characteristics. Neither mucosa color nor papilla counts were affected by $\operatorname{diet}(\mathrm{P}>0.10)$. However, papilla width and the relationship between papillae and their lamina propria thickness were significantly lower $(\mathrm{P}<0.05)$ in animals receiving TMR than those fed CONC.

Table 4 shows mean, maximum, and minimum daily $\mathrm{pH}$ and temperature values, time spent below ruminal $\mathrm{pH}$ thresholds, and areas under the curve. Daily $\mathrm{pH}$ values were higher for CONC than for TMR animals $(\mathrm{P}<0.01)$. All the computed values (daily time at $\mathrm{pH}$ and area under curve), with the exception of time and area under the curve at $\mathrm{pH}$ below 5.4, were higher $(\mathrm{P}<0.05)$ for TMR
Table 2. The effect of offering fattening calves straw + ad libitum concentrate (CONC) as compared with maize silage-based total mixed ration (TMR) on animal performance parameters.

\begin{tabular}{lcccl}
\hline \multirow{2}{*}{$\begin{array}{l}\text { Animal performance } \\
\text { parameters }\end{array}$} & CONC & TMR & SED & P-value \\
\cline { 2 - 5 } Age at slaughter, $\mathrm{d}$ & 405 & 431 & 35.0 & 0.475 \\
Average daily gain, $\mathrm{kg} \mathrm{d}^{-1}$ & 1.40 & 1.31 & 0.097 & 0.390 \\
Carcass weight, $\mathrm{kg}$ & 289 & 298 & 10.9 & 0.464 \\
Dressing percentage & 54.3 & 55.4 & 0.68 & 0.131 \\
\hline
\end{tabular}

SED: Standard error of difference.

Table 3. The effect of offering fattening calves straw + ad libitum concentrate (CONC) as compared with maize silage-based total mixed ration (TMR) on ruminal mucosa characteristics.

\begin{tabular}{|c|c|c|c|c|}
\hline \multirow{2}{*}{$\begin{array}{l}\text { Ruminal mucosa } \\
\text { characteristics }\end{array}$} & \multicolumn{4}{|c|}{ Diet } \\
\hline & $\mathrm{CONC}$ & TMR & SED & $\overline{P \text {-value }}$ \\
\hline \multicolumn{5}{|l|}{ Ruminal mucosa color } \\
\hline Subjective (1: clear; 2 : dark) & 1.71 & 2.00 & 0.184 & 0.147 \\
\hline $\mathrm{R}$ (red index) & 77.0 & 75.5 & 13.02 & 0.909 \\
\hline $\mathrm{G}$ (green index) & 65.0 & 63.1 & 10.38 & 0.859 \\
\hline $\mathrm{B}$ (blue index) & 48.0 & 49.1 & 8.06 & 0.900 \\
\hline Gray (gray scale) & 66.7 & 64.9 & 10.86 & 0.876 \\
\hline Papillae $\mathrm{cm}^{-2}$ & 70.0 & 59.5 & 13.16 & 0.452 \\
\hline Papilla width (AT), $\mu \mathrm{m}$ & 423 & 356 & 30.2 & 0.046 \\
\hline Lamina propria thickness (ALP), $\mu \mathrm{m}$ & 118 & 123 & 8.4 & 0.593 \\
\hline Internal width $(\mathrm{AT}-\mathrm{ALP}) / 2, \mu \mathrm{m}$ & 152 & 117 & 14.3 & 0.028 \\
\hline
\end{tabular}

SED: Standard error of difference.

animals. The diet $x$ day interaction observed for some of the studied parameters could indicate that the effect can vary throughout the day and between days.

Besides the day effect, no significant changes were observed between experimental groups in those parameters related to temperature or the estimated number of times that the animals were drinking per day $(\mathrm{P}>0.10)$ (Table 4).

\section{DISCUSSION}

\section{Animal performance}

Daily gain data observed in the present study are similar to those published by Casasús et al. (2012) for animals fed under similar feeding systems at similar ages, and performance data fell within the range expected for the Avileña-Negra Ibérica breed according to FernándezPerea and Alenda Jiménez (2004).

Casasús et al. (2012) reported no changes in growth rate, weight, and carcass yield when comparing diets consisting of concentrate or total mixed ration. The absence of differences in performance parameters during the fattening period can be indicative of the adequacy of both rations to meet the animals' needs and achieve optimal growth rates (Moya et al., 2011). Likewise, maize silage, despite being forage, provides high energy content compared with other forages (e.g., grass silage) or grazing, which can result in lower growth rates (Keane et al., 2006).

\section{Ruminal mucosa and $\mathrm{pH}$}

The lack of effect on ruminal mucosa must be highlighted. The slight color change noted by subjective assessment could not be confirmed when objective measures were 
Table 4. The effect of offering fattening calves straw + ad libitum concentrate (CONC) as compared with maize silage-based total mixed ration (TMR) on least square means of ruminal $\mathrm{pH}$ and temperature parameters.

\begin{tabular}{|c|c|c|c|c|c|c|}
\hline & \multicolumn{3}{|c|}{ Diet } & \multicolumn{3}{|c|}{ P-value } \\
\hline & CONC & TMR & SED & Diet & Day & Diet $\times$ Day \\
\hline \multicolumn{7}{|l|}{ Daily pH values } \\
\hline Mean & 6.72 & 6.35 & 0.058 & 0.000 & 0.161 & 0.035 \\
\hline Maximum & 7.19 & 6.92 & 0.054 & 0.002 & 0.043 & 0.006 \\
\hline Minimum & 6.14 & 5.78 & 0.080 & 0.001 & 0.633 & 0.448 \\
\hline \multicolumn{7}{|l|}{ Daily time (min) at $\mathrm{pH}$} \\
\hline$<7.0$ & 1130 & 1381 & 57.4 & 0.011 & 0.955 & 1.000 \\
\hline$<6.6$ & 481 & 1005 & 89.5 & 0.000 & 0.424 & 0.146 \\
\hline$<6.2$ & 136 & 406 & 79.4 & 0.007 & 0.068 & 0.028 \\
\hline$<5.8$ & 19 & 235 & 46.7 & 0.001 & 0.001 & 0.002 \\
\hline$<5.4$ & 0 & 16 & 13.6 & 0.127 & 0.228 & 0.283 \\
\hline \multicolumn{7}{|l|}{ Area under the curve (min $\cdot \mathrm{pH}$ per day) } \\
\hline$<7.0$ & 455 & 941 & 78.7 & 0.000 & 0.137 & 0.025 \\
\hline$<6.6$ & 137 & 435 & 64.1 & 0.001 & 0.080 & 0.034 \\
\hline$<6.2$ & 27 & 177 & 36.3 & 0.001 & 0.015 & 0.036 \\
\hline$<5.8$ & 0 & 48 & 13.8 & 0.003 & 0.040 & 0.080 \\
\hline$<5.4$ & 0 & 1 & 1.6 & 0.555 & 0.682 & 0.683 \\
\hline \multicolumn{7}{|l|}{ Daily temperature values } \\
\hline Mean & 38.76 & 38.78 & 0.153 & 0.936 & 0.015 & 0.746 \\
\hline Maximum & 34.68 & 34.57 & 0.297 & 0.720 & 0.028 & 0.849 \\
\hline Minimum & 39.68 & 39.78 & 0.154 & 0.538 & 0.259 & 0.507 \\
\hline \multicolumn{7}{|l|}{ Daily time $(\min )$ at temperature $\left({ }^{\circ} \mathrm{C}\right)$} \\
\hline$>39.0$ & 643 & 675 & 185.8 & 0.869 & 0.468 & 0.293 \\
\hline$>39.2$ & 435 & 439 & 174.1 & 0.984 & 0.478 & 0.461 \\
\hline$>39.4$ & 215 & 159 & 111.0 & 0.631 & 0.538 & 0.986 \\
\hline$>39.6$ & 93 & 49 & 58.8 & 0.484 & 0.652 & 0.936 \\
\hline \multicolumn{7}{|l|}{ Area under the curve $\left(\min \cdot{ }^{\circ} \mathrm{C}\right.$ per day) } \\
\hline$>39.0$ & 232 & 205 & 90.8 & 0.778 & 0.649 & 0.980 \\
\hline$>39.2$ & 120 & 90 & 56.5 & 0.610 & 0.664 & 0.994 \\
\hline$>39.4$ & 51 & 31 & 28.5 & 0.492 & 0.632 & 0.989 \\
\hline$>39.6$ & 19 & 10 & 12.1 & 0.460 & 0.520 & 0.978 \\
\hline Number of drinks per animal per day & 4.96 & 4.09 & 0.623 & 0.193 & 0.130 & 0.081 \\
\hline
\end{tabular}

SED: Standard error of difference.

taken. Papilla counts were numerically higher $(15 \%)$, while papillae were $19 \%$ wider and had $30 \%$ more internal width ((AT - ALP)/2) in the CONC than in the TMR group. These differences can be related to increases in VFA concentration that determine an increase in absorption surface (Shen et al., 2004; Suárez et al., 2006). In this respect, Resende-Junior et al. (2006) reported that an increase in feeding frequency determined an increase in papilla length and width to promote nutrient absorption.

Over and above economic considerations, diet has clear implications for rumen health and animal welfare. In previous experiments, animals receiving TMR usually showed higher ruminal $\mathrm{pH}$ values than concentrate-fed animals (Bach et al.,2007; Moya et al.,2011). Nevertheless, in the current experiment, the TMR group had lower $\mathrm{pH}$ values than CONC animals. Decreases in ruminal $\mathrm{pH}$ are directly related not only to feed composition ("highconcentrate syndrome') but also to feeding management (space availability in the bunk feeder) and the animals' feeding behavior (number of meals per day, amount of feed eaten at each meal) (Calsamiglia et al., 2012). The $\mathrm{pH}$ values reported here are higher than those reported by Moya et al. (2011) (5.75 and 6.25 for concentrate and silage-based diets, respectively), Bach et al. (2007), and Blanch et al. (2010) (5.49 and 5.92, respectively for concentrate-based dairy rations). These differences can be related to the type of animals and feed composition.

Animals in the CONC group had free access all day to a hopper feeder supplying feed ad libitum, while feed was freshly distributed in the bunk feeder early in the morning to animals in the TMR group where it was available until the next day. This method of feed delivery can determine differences in the food intake pattern between animals although total intake could result unaffected (Schwartzkopf-Genswein et al., 2003). Thus, it is expected that a larger number of animals will try to maximize intake when feed is freshly delivered by going to the bunk feeder in the case of the TMR group, while the animals in the CONC group are expected to spread meals throughout the day. Reduced feeding frequency (once a day) in competitive social conditions can lead to competition between animals, thus reducing the number of meals per day and increasing the amount of feed ingested at each meal (Livshin et al., 1995; Robles et al., 2007; González et al., 2008); this results in a deregulation of the mechanisms to maintain rumen conditions (Schwartzkopf-Genswein et al., 2003). Robles et al. (2007) observed that increasing the frequency of concentrate distribution (from once to twice a day) resulted in more stable rumen conditions and increased maximum $\mathrm{pH}$. Likewise, Soto-Navarro et al. (2000) noted a tendency for $\mathrm{pH}$ to be lower when animals were fed a concentrate diet once a day instead of twice. Taking into account the availability of fresh food throughout the day, our results are consistent with these authors' suggestions. Moreover, it must be taken into account that CONC animals had free access of up to $2 \mathrm{~kg}$ of long barley straw, which could also have helped for a higher fiber intake in CONC compared to TMR animals 
and thus increase rumination and saliva production. These circumstances can also have accounted for the better rumen conditions found in CONC animals (González et al., 2012).

\section{Daily $\mathbf{p H}$ variations}

The feed delivery system can also affect the efficiency of feed utilization. Thus, delivering feed once a day (TMR group) can lead to wasting feed regardless of the amount of feed consumed by the animals, and distributing feed to ensure total consumption can be a cost-effective alternative (Pritchard and Bruns, 2003). Likewise, some feeding patterns can cause excessive consumption at a certain time of day, which would result in an increased incidence of digestive problems. In this respect, hopper feeders supply fresh feed as it is consumed, thus ensuring a consistent and constant consumption over time in the CONC group. Decreases in $\mathrm{pH}$ would be related to large food intake in the hours prior to this. When the evolution of mean $\mathrm{pH}$ throughout the day for each experimental group is analyzed (Figure 1), hourly $\mathrm{pH}$ values are significantly different $(\mathrm{P}<0.05)$ during the day.

As the amount of fermentable matter that reaches the rumen is higher, $\mathrm{pH}$ is lower (Bach et al., 2007). The $\mathrm{pH}$ values tend to peak in the moments before feed intake, begin to fall afterward, and reach the minimum between 3 and $6 \mathrm{~h}$ after feed intake depending on the ration (Duffield et al., 2004; Marden et al., 2005; Palmonari et al., 2010). As acid production decreases, volatile fatty acid absorption and rumen buffer capacity (mainly from saliva) increase, and $\mathrm{pH}$ begins to recover initial values; this process is estimated to last approximately $18 \mathrm{~h}$ (Whitelaw et al., 1970; Maekawa et al., 2002; Palmonari et al., 2010). The $\mathrm{pH}$ pattern observed in TMR animals suggests that most of the feed is consumed as soon as it is delivered. In the present study, animals in the CONC group have a more uniform pattern of $\mathrm{pH}$ decline (more stable mean $\mathrm{pH}$ ) than those in the TMR group (Figure 1). In any case, $\mathrm{pH}$

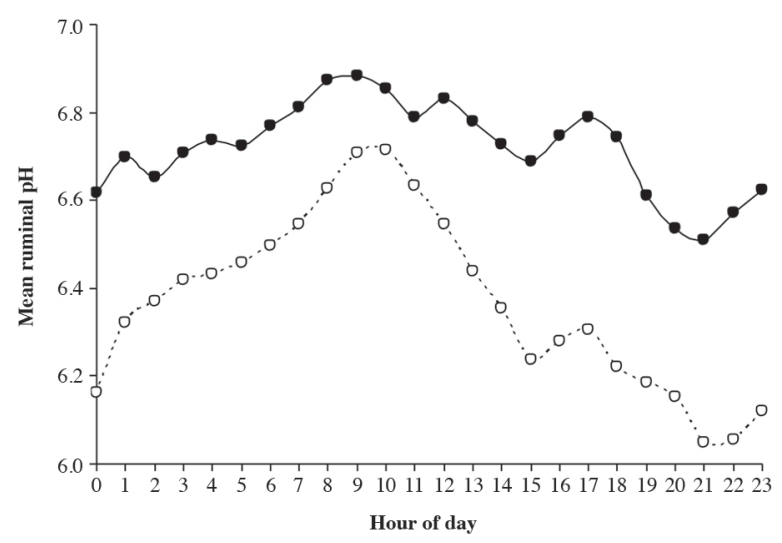

Figure 1. The effect of offering fattening calves straw + ad libitum concentrate $(\mathrm{CONC}, \bullet)$ as compared with maize silage-based total mixed ration (TMR, $\odot$ ) on the evolution of mean $\mathrm{pH}$ values throughout the day. Pairs of values for each hour differ significantly $(P<0.05)$. rises during the night and the maximum value is reached around 09:00-10:00 h for both groups, that is, just before feed is delivered to TMR animals. The nadir is reached at 21:00-22:00 h probably as a consequence of an evening meal for all the animals.

\section{Ruminal temperature}

The intraruminal temperature measurement as an indicator of body temperature is independent of external disturbing factors and cannot be manipulated from the outside although it is approximately $0.5{ }^{\circ} \mathrm{C}$ higher than core body temperature due to the activity of heat-producing rumen microorganisms (Sievers et al., 2004). This makes measuring temperature a suitable and feasible way to detect potential adverse changes in the animals' health in real time (Wahrmund et al., 2012). However, water consumption dramatically reduces ruminal temperature for a period of time proportional to the water temperature and amount of water ingested. It will take between $20 \mathrm{~min}$ and $2 \mathrm{~h}$ for ruminal temperature to recover (Yamada et al., 2001; Bewley et al., 2008).

In this study, no significant linear relationship between ruminal $\mathrm{pH}$ and temperature was observed. Sudden changes in the diet involving rapid and continuous drops in ruminal $\mathrm{pH}$ can lead to increases in ruminal temperature (AlZahal et al., 2007; 2008). In fact, these authors found a significant linear relationship between ruminal $\mathrm{pH}$ and temperature (AlZahal et al., 2008; Wahrmund et al., 2012), which led them to suggest that ruminal temperature can be used to diagnose subacute ruminal acidosis (AlZahal et al., 2008). However, in the present study, no relationship between ruminal $\mathrm{pH}$ and temperature was observed. The fact that animals were not in a ruminal acidosis situation (periods of more than $3 \mathrm{~h}$ at $\mathrm{pH}<5.5$, Wahrmund et al., 2012) and the wide range of $\mathrm{pH}$ and temperature values found in the current experiment compared with the narrow ranges cited by these authors (pH 5 to 5.6 and $39-41{ }^{\circ} \mathrm{C}$, AlZahal et al., 2007; Wahrmund et al., 2012) may have accounted for this lack of relationship.

\section{CONCLUSIONS}

The results of the present study indicate that although animal performance is not affected, feeding fattening calves a concentrate plus barley straw diet can produce better rumen conditions than a maize silage-based TMR.

\section{LITERATURE CITED}

AlZahal, O., E. Kebreab, J. France M. Froetschel, and B.W. McBride. 2008. Ruminal temperature may aid in the detection of subacute ruminal acidosis. Journal of Dairy Science 91:202-207.

AlZahal, O., E. Kebreab, J. France, and B.W. McBride. 2007. A mathematical approach to predicting biological values from ruminal $\mathrm{pH}$ measurements. Journal of Dairy Science 90:37773785 . 
AOAC. 2003. Official methods of analysis. $17^{\text {th }}$ ed. AOAC International, Gaithersburg, Maryland, USA.

Bach, A., C. Iglesias, and M. Devant. 2007. Daily rumen $\mathrm{pH}$ pattern of loose-housed dairy cattle as affected by feeding pattern and live yeast supplementation. Animal Feed Science and Technology 136:146-153.

Benavides, J., M. Martínez-Valladares, M.L. Tejido, F.J. Giráldez, R. Bodas, N. Prieto, et al. 2013. Quercetin and flaxseed included in the diet of fattening lambs: Effect on immune response, stress during transport and ruminal acidosis. Livestock Science 158:8490.

Bewley, J.M., M.W. Grott, M.E. Einstein, and M.M. Schutz. 2008. Impact of intake water temperatures on reticular temperatures of lactating dairy cows. Journal of Dairy Science 91:3880-3887.

Blanch, M., S. Calsamiglia, M. Devant, and A. Bach. 2010. Effects of acarbose on ruminal fermentation, blood metabolites and microbial profile involved in ruminal acidosis in lactating cows fed a high-carbohydrate ration. Journal of Dairy Research 77:123128.

Calsamiglia, S., M. Blanch, A. Ferret, and D. Moya. 2012. Is subacute ruminal acidosis a $\mathrm{pH}$ related problem? Causes and tools for its control. Animal Feed Science and Technology 172:42-50.

Casasús, I., G. Ripoll, and P. Albertí. 2012. Use of maize silage in beef heifers fattening diets: effects on performance, carcass and meat quality. ITEA-Información Técnica Económica Agraria 108:191-206.

Cooke, D.W.I., F.J. Monahan, B.O. Brophy, and M.P. Boland. 2004. Comparison of concentrates or concentrates plus forages in a total mixed ration or discrete ingredient format: effects on beef production parameters and on beef composition, colour, texture and fatty acid profile. Irish Journal of Agricultural and Food Research 43:201-216.

Duffield, T., J.C. Plaizier, A. Fairfield, R. Bagg, G. Vessie, P. Dick, et al. 2004. Comparison of techniques for measurement of rumen $\mathrm{pH}$ in lactating dairy cows. Journal of Dairy Science 87:59-66.

Dye, T.K., and C.J. Richards. 2008. Effect of water consumption on rumen temperature. Journal of Animal Science 86 (Suppl 3):114.

Fernández-Perea, M.T., and R. Alenda Jiménez. 2004. Economic weights for a selection index in Avileña purebred beef cattle. Livestock Production Science 89:223-233.

González, L.A., A. Ferret, X. Manteca, J.L. Ruíz-de-la-Torre, S. Calsamiglia, M. Devant, et al. 2008. Performance, behavior, and welfare of Friesian heifers housed in pens with two, four, and eight individuals per concentrate feeding place. Journal of Animal Science 86:1446-1458.

González, L.A., X. Manteca, S. Calsamiglia, K.S. SchwartzkopfGenswein, and A. Ferret. 2012. Ruminal acidosis in feedlot cattle: Interplay between feed ingredients, rumen function and feeding behavior (a review). Animal Feed Science and Technology 172:66-79.

Keane, M.G., M.J. Drennan, and A.P. Moloney. 2006. Comparison of supplementary concentrate levels with grass silage, separate or total mixed ration feeding, and duration of finishing in beef steers. Livestock Science 103:169-180.

Livshin, N., E. Maltz, and Y. Edan. 1995. Regularity of dairy cow feeding behavior with computer-controlled feeders. Journal of Dairy Science 78:296-304.

Maekawa, M., K.A. Beauchemin, and D.A. Christensen. 2002. Effect of concentrate level and feeding management on chewing activities, saliva production, and ruminal $\mathrm{pH}$ of lactating dairy cows. Journal of Dairy Science 85:1165-1175.

Marden, J.P., C. Bayourthe, F. Enjalbert, and R. Moncoulon. 2005. A new device for measuring kinetics of ruminal $\mathrm{pH}$ and redox potential in dairy cattle. Journal of Dairy Science 88:277-281.

Moya, D., A. Mazzenga, L. Holtshausen G. Cozzi, L.A. González, S. Calsamiglia, et al. 2011. Feeding behavior and ruminal acidosis in beef cattle offered a total mixed ration or dietary components separately. Journal of Animal Science 89:520-530.

Nagaraja, T.G., and E.C. Titgemeyer. 2007. Ruminal acidosis in beef cattle: the current microbiological and nutritional outlook. Journal of Dairy Science 90 (E Suppl.):E17-E38.
Official Journal of the European Union. 2010. Directive 2010/63/ EU of 22 September 2010 on the protection of animals used for scientific purposes. Official Journal of the European Union L276/33-792010. Available at http://eur-lex.europa.eu/ LexUriServ/LexUriServ.do?uri=OJ:L:2010:276:0033:0079:en:P DF (accessed October 2013)

O'Kiely, P. 2011. Intake, growth and feed conversion efficiency of finishing beef cattle offered diets based on triticale, maize or grass silages, or ad libitum concentrates. Irish Journal of Agricultural and Food Research 50:189-207.

Palmonari, A., D.M. Stevenson, D.R. Mertens, C.W. Cruywagen, and P.J. Weimer. 2010. pH dynamics and bacterial community composition in the rumen of lactating dairy cows. Journal of Dairy Science 93:279-287.

Pritchard, R.H., and K.W. Bruns. 2003. Controlling variation in feed intake through bunk management. Journal of Animal Science 81 (E Suppl 2):E133-E138.

Resende-Junior, J.C., L.D.S. Alonso, M.N. Pereira, M.G. Roca Magallanes, E.C. de Oliveira, and L.Q. de Melo. 2006. Effect of the feeding pattern on rumen wall morphology of cows and sheep. Brazilian Journal of Veterinary Research and Animal Science 43:526-536.

Robles, V., L.A. González, A. Ferret, X. Manteca, and S. Calsamiglia. 2007. Effects of feeding frequency on intake, ruminal fermentation, and feeding behavior in heifers fed high-concentrate diets. Journal of Animal Science 85:2538-2547.

Schwartzkopf-Genswein, K.S., K.A. Beauchemin, D.J. Gibb, D.H. Crews, D.D. Hickman, M. Streeter, et al. 2003. Effect of bunk management on feeding behavior, ruminal acidosis and performance of feedlot cattle: A review. Journal of Animal Science 81 (Suppl. 2):E149-E158.

Shen, Z., H.M. Seyfert, B. Löhrke, F. Schneider, R. Zitnan, A. Chudy, et al. 2004. An energy-rich diet causes rumen papillae proliferation associated with more IGF type 1 receptors and increased plasma IGF-1 concentrations in young goats. The Journal of Nutrition 134:11-17.

Sievers, A.K., N.B. Kristensen, H.J. Laue, and S. Wolffram. 2004. Development of an intraruminal device for data sampling and transmission order. Journal of Animal and Feed Sciences 13 (Suppl. 1):207-210.

Soto-Navarro, S.A., C.R. Krehbiel, G.C. Duff, M.L. Galyean, M.S. Brown, and R.L. Steiner. 2000. Influence of feed intake fluctuation and frequency of feeding on nutrient digestion, digesta kinetics, and ruminal fermentation profiles in limit-fed steers. Journal of Animal Science 78:2215-2222.

Suárez, B.J., C.G. Van Reenen, W.J.J. Gerrits, N. Sotckhofe, A.M. van Vuuren, and J. Dijkstra. 2006. Effects of supplementing concentrates differing in carbohydrate composition in veal calf diets: II. Rumen development. Journal of Dairy Science 89:43764386.

Van Soest, P.J., J.B. Robertson, and B.A. Lewis. 1991. Methods for dietary fiber, neutral detergent fiber and nonstarch polysaccharides in relation to animal nutrition. Journal of Dairy Science 74:35833597.

Wahrmund, J.L., J.R. Ronchesel, C.R. Krehbiel, C.L. Goad, S.M. Trost, and C.J. Richards. 2012. Ruminal acidosis challenge impact on ruminal temperature in feedlot cattle. Journal of Animal Science 90:2794-2801.

Walsh, K., P. O'Kiely, A.P. Moloney, and T.M. Boland. 2008. Intake, performance and carcass characteristics of beef cattle offered diets based on whole-crop wheat or forage maize relative to grass silage or ad libitum concentrates. Livestock Science 116:223-236.

Whitelaw, F.G., J. Hyldgaard-Jensen, R.S. Reid, and M.G. Kay. 1970. Volatile fatty acid production in the rumen of cattle given an all-concentrate diet. British Journal of Nutrition 24:179-195.

Yamada, A., M. Sutoh, and T. Imura. 2001. The changes of rumen temperature with grazing behavior in the daytime. Grassland Science 47:491-493. 